\title{
Hyperinsulinaemia and insulin insensitivity: studies in subjects with insulinoma
}

\author{
A. Nankervis ${ }^{1,2}$, J. Proietto ${ }^{1,2}$, P. Aitken ${ }^{1}$ and F. Alford ${ }^{1,2}$ \\ Endocrine Unit and Department of Medicine, University of Melbourne, St. Vincent's Hospital, Fitzroy, Victoria, Australia
}

Summary. Hepatic glucose turnover, peripheral insulin sensitivity and insulin receptor binding were measured in four subjects with insulinoma before and 3 months after surgical resection of the insulinoma. Basal hepatic glucose production, quantitated employing a primed constant infusion of tritiated glucose, was low pre-operatively $\left(5.2 \pm 1.7 \mu \mathrm{mol} \cdot \mathrm{kg}^{-1}\right.$. $\min ^{-1}$ ) but returned to normal post-operatively $(14.9 \pm 2.8$; normal subjects $13.9 \pm 0.8 \mu \mathrm{mol} \cdot \mathrm{kg}^{-1} \cdot \min ^{-1}$ ). Paired euglycaemic dose-response curves were developed for each subject. Insulin sensitivity, expressed as a right shift of the dose-response curve $\left(E D_{50}\right)$, was low pre- and post-operatively. How- ever, insulin responsiveness $\left(\mathrm{V}_{\max }\right)$ remained normal (pre-operatively $13.9 \pm 2.2$, post-operatively $13.8 \pm 0.8$, normal subjects $16.7 \pm 0.8 \mathrm{ml} \cdot \mathrm{kg}^{-1} \cdot \mathrm{min}^{-1}$ ). There was no consistent pattern in monocyte or erythrocyte receptor binding before or after surgery. These data suggest that the chronic hyperinsulinaemia causes suppression of hepatic glucose production, and a state of insulin insensitivity which appears to be due to a post-receptor defect.

Key words: Insulinoma, hyperinsulinaemia, insulin sensitivity, insulin responsiveness.
Hyperinsulinaemia has been noted to be associated with insulin resistance and down regulation of insulin receptors. However, subjects with these abnormalities tend to be obese [1,2], diabetic [3,4] or cirrhotic [5], and it is unclear which is the initial pathological event. The study of subjects with insulinoma presents the opportunity to investigate directly the effects of longstanding primary hyperinsulinaemia on insulin sensitivity and receptor binding. To date only a few studies have addressed this question. Thus, it has been reported that basal hepatic glucose production is suppressed in subjects with insulinoma and is the major cause of fasting hypoglycaemia, whilst peripheral glucose disposal has been found to be normal [6]. Other workers report that glucose clearance is higher in fasting subjects with hyperinsulinaemia $[7,8]$. The effect on glucose turnover of correcting the hyperinsulinaemia by surgical removal of the insulinoma has not been examined.

The object of the present study was to investigate the effects of chronic hyperinsulinaemia on hepatic glucose production, glucose disposal and insulin receptor binding. To this end, insulin dose response curves using the euglycaemic clamp technique were performed, before and after surgical resection, on four subjects with insulinoma.

\section{Subjects and methods}

\section{Subjects}

Studies were performed on four subjects with an insulinoma. These studies were repeated 3 months after successful surgical removal of

Table 1. Clinical and basal biochemical data of fasted insulinoma and control subjects

\begin{tabular}{|c|c|c|c|c|c|c|c|c|c|c|c|}
\hline Subject & $\operatorname{Sex}$ & Age & \multicolumn{2}{|c|}{ Weight (kg) } & Height (m) & \multicolumn{2}{|c|}{ Glucose $(\mathrm{mmol} / \mathrm{l})$} & \multicolumn{2}{|c|}{ IRI (mU/l) } & \multicolumn{2}{|c|}{ IRG $(\mathrm{pg} / \mathrm{ml})$} \\
\hline 1 & $\mathrm{~F}$ & 51 & 58 & 65 & 1.48 & 2.7 & 4.9 & 24 & 10 & 24 & 41 \\
\hline 3 & M & 24 & 85 & 58 & 1.54 & 3.8 & 6.2 & 12 & 7 & 58 & - \\
\hline 4 & M & 27 & 75 & 70 & 1.47 & 2.4 & 5.5 & 25 & 15 & 72 & 181 \\
\hline
\end{tabular}


the insulinoma, and in one subject a further 18 months after surgery. All had presented with classical symptoms of fasting hypoglycaemia of 4 to 24 months' duration, and were found to have low fasting blood glucose and elevated plasma insulin levels. Clinical and basal biochemical details are shown in Table 1. Oral glucose tolerance tests were not performed in the insulinoma subjects pre-operatively. At surgery each subject was found to have a pancreatic tumour which was completely removed. Histology and immunocytochemistry confirmed the tumours to be insulin-secreting islet cell adenomas. The postoperative course was uneventful in all but one subject (subject 2) who developed congestive cardiac failure which necessitated treatment. All subjects were in good health at the time of the second study, and digoxin and furosemide medication was withdrawn $48 \mathrm{~h}$ before the study in subject 2 . Three subjects lost weight following surgery; two returned to what they considered to be normal weight, and one had persistent, although mild, anorexia. The control subjects were normal, healthy, ambulant volunteers on no medication. One insulinoma subject was older (76years) than any of the control subjects (mean age 38 years). Written informed consent was obtained from all subjects, and the protocol was approved by the Ethics and Research Committee of St.Vincent's Hospital, Melbourne.

\section{Study protocol}

All subjects were studied after an 8 -h fast and a 30 -min period of recumbency. Solutions were infused using a Minipuls pump (Gilson, Villiers-Le-Belle, France) through a $20-\mathrm{cm}$ Intracath placed in an antecubital vein. Blood samples were collected from an indwelling butterfly needle placed in the contralateral dorsal hand vein. To avoid problems due to adsorption to tubing, insulin was added to normal saline $(0.9 \%)$ and pre-run for $1 \mathrm{~h}$ before use. Blood for hormone estimation was collected in 10\% Aprotinin (Trasylol, Bayer Pharmaceutical Company, Botany, Australia) promptly centrifuged at $1500 \mathrm{~g}$ for $5 \mathrm{~min}$ and the plasma stored at $-20^{\circ} \mathrm{C}$ until the time of assay.

Basal glucose turnover was measured in three of the subjects, using a primed constant infusion of ${ }^{3} \mathrm{H}-3$ glucose, with the glucose pool appropriately primed with an intravenous bolus dose of ${ }^{3} \mathrm{H}-3$ glucose [9-11]. In two of the subjects $20 \%$ dextrose was infused basally to prevent hypoglycaemia (subject 1: $0.96 \mathrm{ml} \cdot \mathrm{kg}^{-1} \cdot \mathrm{h}^{-1}$; subject 2: $0.51 \mathrm{ml} \cdot \mathrm{kg}^{-1} \cdot \mathrm{h}^{-1}$ ). Sixty minutes were allowed to achieve steady state. Glucose levels remained steady over the last hour, and samples for insulin and glucose were taken at 10-min intervals over the last $30 \min [12]$.

Insulin dose response curves were constructed as reported previously [12]. Insulin was infused at a rate ranging from 40 to $600 \mathrm{mU}$. $\mathrm{kg}^{-1} \cdot \mathrm{h}^{-1}$ for each insulin plateau. In view of previous studies [9], hepatic glucose production was assumed to be suppressed to insignificant values during the insulin infusion periods. Euglycaemia was maintained throughout, employing the modification [12] of the euglycaemic clamp as described by De Fronzo et al. [13]. In three subjects, three-point dose rosponse curves were performed in a single day. One subject (subject 4) had a five-point dose response curve constructed over 2 days.

\section{Calculations}

The rate of appearance of glucose ( $\mathrm{Ra}$ ) at steady state was calculated from the formula $\mathrm{Ra}=\mathrm{F} / \mathrm{SA}$, where $\mathrm{F}=$ rate of infusion of tritiated glucose and $\mathrm{SA}=$ specific activity of the plasma tritiated glucose at steady state [14]. Steady state was defined as $<10 \%$ variation in the counts, specific activity and plasma glucose levels at the time of plateau. For all studies the mean coefficient of variation for plateau glucose levels and plateau counts were $5.5 \pm 0.2 \%$ and $5.7 \pm 0.8 \%$, respectively. In those studies in which the criteria for steady state were not met, the non-steady state equation of Steele, with a pool fraction of 0.65 , was used to calculate Ra [14]. During the insulin infusion periods where it was assumed hepatic glucose production was suppressed to insignificant values, $\mathrm{Ra}=$ the rate of infusion of glucose. When the plasma glucose is stable, $\mathrm{Ra}=\mathrm{Rd}$ (rate of disappearance of glucose),
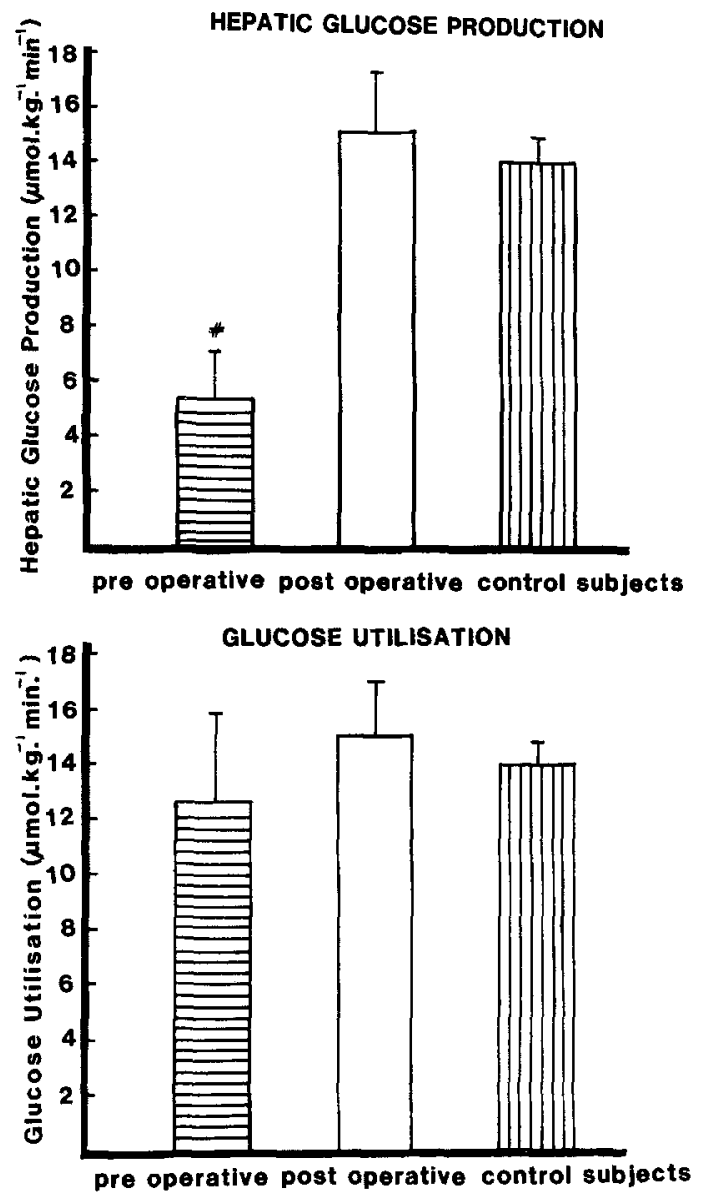

Fig. 1. Hepatic glucose production and glucose utilization in pre-operative, post-operative and control subjects. $p<0.01$ postoperative versus control subjects

and the rate of utilization of glucose (Rut) $=\mathrm{Rd}$ when there is no urinary glucose loss. Metabolic clearance rate of glucose $\left(\mathrm{MCR}_{\mathrm{G}}\right)$ is calculated as $\mathrm{Rd} / \mathrm{G}$ where $\mathrm{G}$ is the stable plasma glucose concentration. As previously discussed, the dose-response curves were constructed by plotting the glucose disposal rate, measured as $\mathrm{MCR}_{\mathrm{G}}$, against the steady state plasma insulin (IRI) levels $[12,15]$. The curvilinear insulin dose-response curves were linearized, employing the transformation [IRI] $/ \mathrm{MCR}_{\mathrm{G}}$ versus [IRI] $[12,16]$. The advantages of the method used here to develop the dose-response curves have been previously discussed [12]. Briefly, the method ensures that steady state conditions apply at the time of sampling, the estimation of $\mathrm{MCR}_{\mathrm{G}}$ is independent of small differences in plasma glucose levels between individual subjects, and extremely high rates of insulin infusion are not required. The use of $\mathrm{MCR}_{\mathrm{G}}$ has been shown to be appropriate provided that insulin levels are $>25 \mathrm{mU} / 1$; the studies were carried out at comparable, if not identical, euglycaemia [12].

\section{Analytical procedures}

Blood glucose was measured with a Centrifichem $\mathrm{C} 400$ analyser (Union Carbide Corporation, New York), using a hexokinase method. Plasma IRI was estimated by radioimmunoassay using dextrancharcoal separation of bound and free fractions [17]. Assay sensitivity for IRI was $1 \mathrm{mU} / 1$ with an interassay coefficient of variation at $22 \mathrm{mU} / 1$ of $8.4 \%$. Blood for glucagon (IRG) estimation was collected into chilled, heparinised tubes containing 5,000 KIU aprotinin (Trasylol, Bayer Pharmaceuticals, Botany, Australia). Plasma IRG was estimated by radioimmunoassay employing the pancreatic glucagon specific (C terminal reacting) antiserum RCS5 (kindly donated by Dr. 


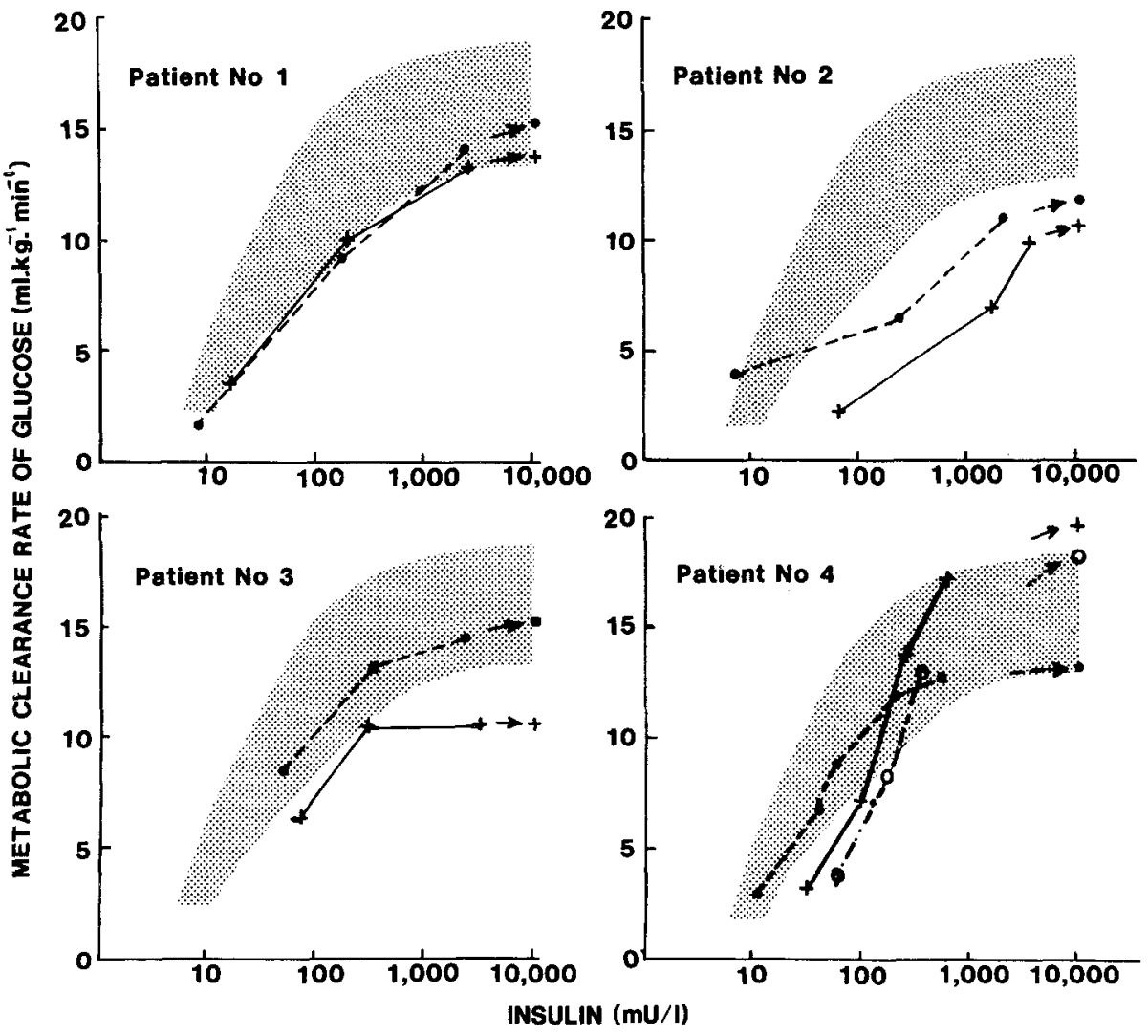

Fig. 2. Dose response curves constructed by plotting glucose disposal (measured as the metabolic clearance rate of glucose) at euglycaemia against plasma insulin levels in the four subjects with insulinoma. The pre-operative curve $(-+-)$, postoperative curve $(--0--), 18$ month postoperative curve $(\cdot . \cdot \mathrm{O} \cdot . \cdot)$ are shown in relation to the normal range (shaded area; mean $+\mathrm{SEM}$ ). Calculated $\mathrm{V}_{\max }$ is indicated at the insulin level $10,000 \mathrm{mU} / 1$
Table 2. Basal glucose turnover and calculated dose response curve and insulin receptor data on insulinoma and control subjects

\begin{tabular}{|c|c|c|c|c|}
\hline $\begin{array}{l}\text { Insulinoma } \\
\text { subjects }\end{array}$ & & $\begin{array}{l}\text { Hepatic } \\
\text { glucose } \\
\text { production } \\
\left(\mu \mathrm{mol} \cdot \mathrm{kg}^{-1}\right. \\
\left.\cdot \min ^{-1}\right)\end{array}$ & $\begin{array}{l}\mathrm{ED}_{50}^{\mathrm{a}} \\
(\mathrm{mU} / \mathrm{l})\end{array}$ & $\begin{array}{l}\mathrm{V}_{\max } \\
\left(\mathrm{ml} \cdot \mathrm{kg}^{-1}\right. \\
\left.\cdot \min ^{-1}\right)\end{array}$ \\
\hline 1 & $\begin{array}{l}\text { Pre-operative } \\
\text { Post-operative }\end{array}$ & $\begin{array}{l}7.4 \\
9.4\end{array}$ & $\begin{array}{l}51 \\
97\end{array}$ & $\begin{array}{l}14.0 \\
15.1\end{array}$ \\
\hline 2 & $\begin{array}{l}\text { Pre-operative } \\
\text { Post-operative }\end{array}$ & $\begin{array}{r}1.1 \\
18.5\end{array}$ & $\begin{array}{l}370 \\
345\end{array}$ & $\begin{array}{l}10.8 \\
11.9\end{array}$ \\
\hline 3 & $\begin{array}{l}\text { Pre-operative } \\
\text { Post-operative }\end{array}$ & $\begin{array}{l}- \\
-\end{array}$ & $\begin{array}{l}70 \\
58\end{array}$ & $\begin{array}{l}10.7 \\
15.2\end{array}$ \\
\hline 4 & $\begin{array}{l}\text { Pre-operative } \\
\text { Post-operative } \\
18 \text { months post- } \\
\text { operative }\end{array}$ & $\begin{array}{r}7.2 \\
16.7 \\
-\end{array}$ & $\begin{array}{r}147 \\
70 \\
200\end{array}$ & $\begin{array}{l}19.9 \\
13.1 \\
18.3\end{array}$ \\
\hline Mean \pm SEM & $\begin{array}{l}\text { Pre-operative } \\
\text { Post-operative }\end{array}$ & $\begin{array}{r}5.2 \pm 1.7^{\mathrm{b}} \\
14.9 \pm 2.8\end{array}$ & $\begin{array}{l}159 \pm 73^{b} \\
143 \pm 59^{b}\end{array}$ & $\begin{array}{l}13.9 \pm 2.2 \\
13.8 \pm 0.8\end{array}$ \\
\hline $\begin{array}{l}\text { Control } \\
\text { subjects }\end{array}$ & & $13.9 \pm 0.8$ & $51 \pm 6$ & $16.7 \pm 0.8$ \\
\hline
\end{tabular}

Results expressed as mean $\pm \mathrm{SEM}$. ${ }^{\text {a }} \mathrm{ED}_{50}$ : Insulin level at which half maximal effect occurs. ${ }^{\mathrm{b}} p<0.05$ compared with control subjects

S. R. Bloom, Hammersmith Hospital, London, UK) using dextran charcoal separation [18]. Assay sensitivity for IRG was $14 \mathrm{pg} / \mathrm{ml}$ with interassay coefficient of variation being $24 \%$ at $95 \mathrm{pg} / \mathrm{ml}$. C-peptide was measured using the Novo kit (Novo Research Institute, Copenhagen, Denmark) with antiserum M1230. All samples were extracted with $25 \%$ polyethylene glycol before measurement of C-peptide activity [19]. Binding of ${ }^{125} \mathrm{I}$-insulin to human erythrocytes was measured using the method of Gambhir et al. [20]. Leucocytes for the monocyte receptor assay were isolated by the Ficoll-Hypaque technique, as described by Boyum [21]. Binding was measured using a radioimmunoassay in which separation of monocyte-bound radioactivity from buffer-radioactivity was achieved through dibutyl phthalate, and the cell pellet counted for cell associated radioactivity. Cell binding was standardized to $5 \times 10^{6}$ monocytes.

\section{Statistical analysis}

Linear regression analysis of the dose-response curve data [12] and paired and non-paired t-tests were performed by standard statistical techniques. Results are presented as mean \pm SEM.

\section{Results}

Fasting blood glucose levels in the insulinoma subjects pre-operatively were lower than the treated insulinoma subjects and the normal controls $(3.0 \pm 0.3,5.5 \pm 0.3$ and $3.8 \pm 0.2 \mathrm{mmol} / 1$ respectively; $p<0.001$; Table 1$)$. As expected, fasting IRI levels in the untreated insulinoma subjects were elevated $(34.5 \mathrm{mU} / 1 ; p<0.05$ versus normal subjects), but had fallen to $10 \mathrm{mU} / 1$ post-operative$1 y$, to be within the normal range. Hepatic glucose production in the insulinoma subjects before surgery was low $\left(5.2 \pm 1.7 \mu \mathrm{mol} \cdot \mathrm{kg}^{-1} \cdot \mathrm{min}^{-1} ; p<0.001\right)$, consistent with the elevated basal insulin level (Table1; Fig.1). Following surgery, and the return of fasting IRI levels to normal, basal hepatic glucose production rose to $14.9 \pm 2.8 \mu \mathrm{mol} \cdot \mathrm{kg}^{1} \cdot \mathrm{min}^{-1}$, which was similar to 
that found in normal subjects $\left(13.9 \pm 0.8 \mu \mathrm{mol} \cdot \mathrm{kg}^{-1}\right.$. $\min ^{-1}$ ). Basal glucose utilization is difficult to interpret because of differences in fasting IRI levels in the insulinoma subjects. However, there was no significant difference between the hyperinsulinaemic insulinoma subjects and control subjects with normal insulin levels $\left(12.6 \pm 3.1 \mu \mathrm{mol} \cdot \mathrm{kg}^{-1} \cdot \mathrm{min}^{-1}\right.$ pre-operatively, $14.9 \pm$ 2.3 post-operatively, $13.9 \pm 0.8$ normal subjects; Fig.1). Basal IRG levels are shown in Table 1. Values tended to be lower pre-operatively but did not differ significantly from post-operative levels, which, with one exception, fell within the normal range.

Individual euglycaemic dose-response curves showing IRI plotted against $\mathrm{MCR}_{\mathrm{G}}$ are shown in Figure 2. In all insulinoma subjects pre-operatively the curves were right-shifted at the lower insulin levels, lying either just within or below the normal range. Post-operatively the curve moved to the left in subjects 3 and 4, remained just outside the normal range in subject 1 , and stayed markedly to the right in subject 2 . In one subject (subject 4) the right shift in the dose response curve was noted again in the study 18 months post-operatively. Thus, insulin sensitivity, expressed as the insulin level at which half maximal biological effect occurs $\left(\mathrm{ED}_{50}\right)$ was decreased in the insulinoma subjects pre-operatively $(159 \pm 73 \mathrm{mU} / \mathrm{l} ; p<0.05)$ and did not change $(143 \pm$ $59 \mathrm{mU} / 1$ ), although the $\mathrm{ED}_{50}$ was normal in two subjects and the dose response curve had shifted to the left in three subjects post-operatively. This compares with an $\mathrm{ED}_{50}$ of $51 \pm 6 \mathrm{mU} / 1$ in control subjects. There was a strong positive correlation between fasting insulin levels in the insulinoma subjects and the $\mathrm{ED}_{50}(r=0.99 ; p<$ 0.01 ). Insulin responsiveness in the untreated diabetic subjects was not statistically different to that found in normal subjects $\left(13.9 \pm 2.2\right.$ versus $16.7 \pm 0.8 \mathrm{ml} \cdot \mathrm{kg}^{-1}$. $\left.\min ^{-1}\right)$ and did not change following surgery (13.8 \pm $0.8 \mathrm{ml} \cdot \mathrm{kg}^{-1} \cdot \min ^{-1} ;$ Fig. 2, Table 2).

There were no consistent changes in monocyte or erythrocyte binding characteristics in the subjects with insulinoma before surgery and no pattern of change following surgery.

\section{Discussion}

The aetiology of hypoglycaemia in subjects with insulinoma is thought to be largely due to suppression of hepatic glucose production $[6,8]$, rather than to increased glucose utilization, although the clearance rate of glucose has been noted to be elevated [6]. Our studies also demonstrated a marked suppression of hepatic glucose production in the fasting state. In two subjects a small quantity of glucose was infused basally but this was only sufficient to maintain euglycaemia and so it seems that suppression of endogenous glucose output is predominantly a direct response to prevailing hyperinsulinaemia. This suppression is completely reversed by surgical resection of the insulinoma and the return of insulin levels to normal.

Glucose utilization and metabolic clearance rate of glucose were not increased in our fasting insulinoma subjects. Construction of dose-response curves reveals that glucose clearance is actually diminished at lower insulin levels as demonstrated by the right shift of the dose response curves, and the higher $\mathrm{ED}_{50}$ estimation. The strong positive correlation between the fasting insulin level and $\mathrm{ED}_{50}$ supports the concept that the degree of the hyperinsulinaemia relates to the magnitude of the insulin resistance [5]. Either receptor down regulation, or a defect in a rate limiting step of intracellular glucose metabolism could be the cause of this resistance. Measurement of insulin receptor binding and numbers reveals no consistent pattern, although other studies have reported a tendency for binding to be lower [22]. This implies that a post receptor defect in insulin action is likely to exist in these subjects although this conclusion is only true if the measurement of insulin binding to monocytes and erythrocytes reflects in vivo insulin binding to insulin sensitive tissues, such as muscle or fat [23]. As glucagon levels were normal in subjects with insulinoma both pre- and post-operatively, this hormone cannot be implicated as a cause of insulin insensitivity [24].

Insulin responsiveness in subjects with hyperinsulinaemia is normal, so it is apparent that insulin is capable of exerting its full biological effect on peripheral tissues, although this effect occurs at higher insulin levels than in normal subjects. Other workers $[5,25]$ in investigating the aetiology of insulin resistance in cirrhosis and hypercortisolaemia also found right shifted dose response curves in the presence of normal insulin receptor binding. Thus, the present study further supports the view of Proietto et al. [5], that post-receptor abnormalities can be rate-limiting at sub-maximal insulin concentrations, while not impeding the full biological effect at maximal concentrations. Interestingly, Kobayashi et al. and Trimble et al. [26-28] have demonstrated that cells of hyperinsulinaemic rats exhibit increased activity of intracellular glucose metabolism and the glucose transport system, reflected by an increase of $V_{\max }$. Our hyperinsulinaemic subjects failed to demonstrate such an increase in $V_{\max }$.

Following removal of the insulinoma and the return of fasting insulin levels to the normal range, insulin responsiveness is unchanged. Peripheral insulin sensitivity was normal in two subjects and markedly impaired in one subject. It was thought that 3 months may not have been long enough to completely reverse any abnormality and therefore one subject was studied again 18 months post-operatively. Insulin insensitivity was again noted in this subject and underscores the suggestion that impaired insulin sensitivity might be a prolonged result of hyperinsulinaemia.

We therefore conclude that basal hepatic glucose production is decreased appropriately in response to 
the prevailing hyperinsulinaemia, and this appears to be the predominant cause of fasting hypoglycaemia of insulinoma subjects. However, the hyperinsulinaemia appears also to be associated with a state of insulin insensitivity. This insensitivity may be due to a post receptor defect, although the aetiology and site of this defet are not clear at the present time.

Acknowledgements. A. Nankervis and J.Proietto were recipients of National Health and Medical Research Scholarships. We are grateful to M. Harewood for his expert technical assistance, and E. Mobilio for her assistance in the preparation of this paper. This work was supported by the National Health and Medical Research Council of Australia, John Claude Kellion Foundation and Novo Laboratories (Australia) Pty. Ltd.

\section{References}

1. Harrison LC, Martin FIR, Melick RA (1976) Correlation between insulin receptor binding in isolated fat cells and insulin sensitivity in obese human subjects. J Clin Invest 58: 1435-1441

2. Kolterman OG, Reaven GM, Olefsky JM (1979) Relationship between in vivo insulin resistance and decreased insulin receptors in obese man. J Clin Endocrinol Metab 48: 487-494

3. Lockwood DH, Hamilton CL, Livingston JN (1979) The influence of obesity and diabetes in the monkey on insulin and glucagon binding to liver membranes. Endocrinol 104: 76-81

4. Olefsky JM (1976) The insulin receptor: Its role in insulin resistance of obesity and diabetes. Diabetes $25: 1154-1162$

5. Proietto J, Nankervis A, Aitken P, Dudley FJ, Caruso G, Alford FP (1984) Insulin resistance in cirrhosis: Evidence for a post-receptor defect. Clin Endocrinol 21: 677-688

6. Rizza RA, Haymond MW, Verdonk CA, Mandarino LJ, Miles JM, Service FJ, Gerich JE (1981) Pathogenesis of hypoglycemia in insulinoma patients. Diabetes 30: 377-381

7. Pontiroli AE, Secchi A, Dabandi M, Alberetto M, Bosi E, Fantaguzzi S, Pozza G (1983) Study of hypoglycemic patients by the glucose clamp technique using the artificial pancreas. J Clin Endocrinol Metab 57: 1297-1300

8. Bougneres PG, Ferre P, Chaussain JL, Job JC (1983) Glucose metabolism in hyperinsulinemic infants: the effects of fasting and sodium DL- $\beta$-hydroxybutyrate on glucose production and utilization rates. J Clin Endocrinol Metab 57: 1054-1060

9. Nankervis A, Proietto J, Aitken P, Harewood M, Alford F (1982) Differential effects of insulin therapy on hepatic and peripheral insulin sensitivity in Type 2 (non-insulin-dependent) diabetes. Diabetologia 23: $320-325$

10. Altszuler N, Bardai A, Bjerkes C, Gottlieb B, Steele R (1975) Glucose turnover values in the dog obtained with various species of labelled glucose. Am J Physiol 229: 1662-1667

11. Proietto J, Alford F, Dudley F (1980) The mechanism of carbohydrate intolerance of cirrhosis. J Clin Endocrinol Metab 51: 1030-1036

12. Proietto J, Harewood M, Aitken P, Nankervis A, Caruso G, Alford $F$ (1982) Validation of a practical in vivo insulin dose-response curve in man. Metabolism 31:354-360
13. De Fronzo RA, Tobin JD, Andres R (1979) Glucose clamp technique: A method for quantifying insulin secretion and resistance. Am J Physiol 237 (3): E214-223

14. Steele R (1959) Influences of glucose loading and injected insulin on hepatic glucose output. Ann NY Acad Sci 82: 420-430

15. Proietto J, Nankervis A, Aitken P, Caruso G, Harewood M, Alford F (1983) The physiologic action of insulin on glucose uptake and its relevance to the interpretation of the metabolic clearance rate of glucose. Metabolism 32: 1022-1028

16. Rigg DA (1963) The mathematical approach to physiological problems. Williams \& Wilkins, Baltimore, pp 913-929

17. Albano J, Ekins RP, Maritz G, Turner R (1972) A sensitive precise radioimmunoassay of serum insulin relying on charcoal separation of bound and free hormone moieties. Acta Endocrinol 70: 487-509

18. Alford F, Bloom S, Nabarro J (1977) Glucagon levels in normal and diabetic subjects: use of a specific immunoabsorbent for glucagon radioimmunoassay. Diabetologia 13:1-6

19. Heding L (1975) Radioimmunological determination of human $C$ peptide in serum. Diabetologia 11:541-548

20. Gambhir K, Archer J, Carter L (1977) Insulin radioreceptor assay for human erythrocytes. Clin Chem 23: 1590-1595

21. Boyum A (1968). Isolation of mononuclear cells and granulocytes from human blood. Scand J Clin Lab Invest (Suppl 97), 21: 77-89

22. Bar RS, Gorden P, Roth J, Sieber CW (1977) Insulin receptors in patients with insulinomas: changes in receptor affinity and concentration. J Clin Endocrinol Metab 44: 1210-1213

23. Pedersen O (1983) Insulin receptor assays used in human studies: Merits and Limitations. Diabetes Care. 6: 301-309

24. Nankervis A, Proietto J, Ng KW, Alford F, Larkins R (1981) The Metabolic effects of chronic hyperglucagonaemia. Clin Endocrinol 15: 325-333

25. Rizza RA, Mandarino LJ, Gerich JE (1982) Cortisol-induced insulin resistance in man: impaired suppression of glucose production and stimulation of glucose utilization due to a post-receptor defect of insulin action. J Clin Endocrinol Metab 54: 131-138

26. Kobayashi M, Olefsky JM (1979) Effect of Experimental hyperinsulinaemia on intracellular glucose metabolism of isolated adipocytes. Diabetologia 17:111-116

27. Kobayashi M, Olefsky JM (1978) Long-term regulation of adipocyte glucose transport capacity by circulating insulin in rats. J Clin Invest 62: 73-81

28. Trimble ER, Weir GC, Gjinovci A, Assimacopoulos-Jeannet F, Benzi R, Renold AE (1984) Increased insulin responsiveness in vivo and in vitro consequent to induced hyperinsulinemia in the rat. Diabetes 33: 444-449

Received: 17 December 1984

and in revised form: 22 May 1985

Dr. A. Nankervis

Department of Medicine

University of Melbourne

The Royal Melbourne Hospital

Melbourne, Victoria 3050

Australia 